\title{
Belgeo
}

Revue belge de géographie

\section{The tourist route system - models of travelling patterns}

Le système de l'itinéraire touristique-modèles de schémas de voyage

\section{Thor Flognfeldt jr.}

\section{(2) OpenEdition \\ 1 Journals}

\section{Electronic version}

URL: http://journals.openedition.org/belgeo/12406

DOI: 10.4000/belgeo.12406

ISSN: 2294-9135

\section{Publisher:}

National Committee of Geography of Belgium, Société Royale Belge de Géographie

\section{Printed version}

Date of publication: 30 June 2005

Number of pages: $35-58$

ISSN: 1377-2368

\section{Electronic reference}

Thor Flognfeldt jr., "The tourist route system - models of travelling patterns", Belgeo [Online], 1-2 I

2005, Online since 27 October 2013, connection on 05 February 2021. URL: http://

journals.openedition.org/belgeo/12406 ; DOI: https://doi.org/10.4000/belgeo.12406

This text was automatically generated on 5 February 2021.

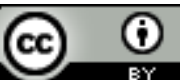

Belgeo est mis à disposition selon les termes de la licence Creative Commons Attribution 4.0 International. 


\section{The tourist route system - models of travelling patterns}

Le système de l'itinéraire touristique - modèles de schémas de voyage

Thor Flognfeldt jr.

\section{The tourist route system - models of traveling patterns}

"Travel to and from the destination site and experiences associated with these phases have been ignored. A better understanding of travel behaviour could assist in the marketing of secondary trips, staging areas, and minor attractions located in the vicinity of larger, more popular destinations. Such relationship requires the cooperation of the psychologist and the tourist professional. Travellers, not laboratory subjects, must be studied in transit, at hotels, in their homes, and on site. The tourist professional can make this integrative work possible by being sensitive to the importance and implications of this type of research." (Fridgen, 1984, p. 33).

1 Even though Fridgen is a social psychologist and this author is a geographer, our shared interest is in studying what happens during travel to and from a destination as an attempt of trying to understand the whole trip behaviour. Without such an understanding of the complete trip my view is that much of the on destination studies will be lacking important information. Since most tourists "like travelling", their en route behaviour must be regarded as an integrated part of their complete travel experiences.

2 This paper is about "routes", "sites" and "tourists". Numerous volumes have defined "the tourist", and those will not be repeated here. The focus of this presentation will, instead, mainly be on the routes used by the tourists and sometimes also about the sites along these routes. Of course, definitions of tourist and traveller types and segments will be used in connection with models and analysis.

Routes were important parts of the tourist products even long before tourism was defined. Some of the ancient routes are very well known, and among those is the name 
of the country this author comes from - Norge - or Norway - meaning the route northwards. That route was, of course, the waterway along the long coastline northwards. Transport by boats was the only way of moving rapidly in a mountainous country, before building the railways.

4 The early travel routes were either parts of a trading system or connected to religious practices. Most of the route names are created later on, to explain the subject of a route or the direction. The Silk Route through Asia is one example, the pilgrimage routes from Central Europe to Nidaros (present day Trondheim) in Norway might be another. The first real system of tourism routes might have been the Grand Tour, a complex network of routes more or less all leading to Rome (Towner, 1996).

5 The tour operated routes are just one and a half century old. The first organized tours were Ths. Cook's from 1841. In Norway Ths. Bennett started his similar practice not long afterwards.

6 The invention of cars and later on motor coaches meant new possibilities of travel. Roads, however, were mainly built for other than tourism and recreation purposes. The system of Scenic Byways in the US started as early as 1913 (Lew, 1991). Since then the system is developed to be present in most US states. In addition to signs and maps, there are specialized handbooks available for some of those routes. Green routes were first just an indication on maps (i.e., maps provided by Michelin or Hallwag). The summer of 1998 marked the first official use of such sign-posted routes in Norway named National Tourist Roads.

7 The explosion of travel guidebooks and travel programmes on TV, in some countries also separate travel channels, have also contributed to the rapid emerging systems of themed routes. Both media are in the need of "telling a story" - and a travel along a touristic route fills well into such needs.

8 Another route system is those used by the world around travellers. According to Pryer (1997) is there a group of "mature adventurists" who have been travelling around the world for years either because they have financial means for this or they are "working their way around". This group does not need travel handbooks and so on, but might later on be handbook authors. They are in a way setting up routes for others to use.

Governing was also an important reason for travel in Norway as elsewhere in Europe, and a system of inns (in Norwegian "skysstasjoner") were located along the routes, mainly to cater for the travel of the King's men. Providing accommodation or meals and changing horses were the duties of innkeepers, who in addition could sell their beds to other prosperous travellers.

10 Such inns are well known and their location documented, as are the routes these travellers used. At the same time there existed another accommodation system less known - "travellers rest houses" (in Norwergian "ferdmannskviler"). This was a system giving permits to some small farms or houses along the roads to accommodate travellers needing a shelter and a meal. Such shelters could be a single room with one large bed or some beds. Travelling salesmen, transporters, farmers bringing their goods to far away markets and migrants mingled together is such shelters. Those who grew up in such house were often well educated in national and international events, since the travellers had very much to tell (Forfang, 1978-85). Today, both inns and rest houses still might be part of the en route accommodation system, even though their names have changed and the houses are rebuilt or improved. 
11 During the last two decades specially designed touristic routes have come more into focus all over the world - especially themed routes like Wine Tours, Bier Route (Bavaria, Germany), Malt Whisky Trail (Scotland), Belgian Textile Route, Franco-Swiss Clock Route, Glass Trail (Sweden) and Romantische Strasse (Germany). But also more general Scenic or Green Routes has been promoted, often to get tourists to drive outside the main highways. Even old Pilgrimage tracks have been reopened and designed for both tourists and "new" pilgrims (Maier, Ludwig \& Oergel, 1994; Dewailly, 1998; Delbaere, 1994)

12 Tourism and travel as research themes are not based on a single theory, but a series of models of which some contains basic definitions that most researchers agree on. One of these common agreements is that being a tourist means leaving home, then travelling on a route, and at last returning home. Leiper $(1979,1989)$ has described this process in a basic model (figures 2 and 3 ).

13 Sites are also important parts of the trips. They must, however, be viewed and sorted according to their roles within the complete trip, not always as the site of the trip. Our findings show that every site on a specified route might also have something that makes a stop at this site special for at least one segment of travellers. Most tourism studies and textbooks, however, still "seem to pretend" that tourism is happening at a single site or in a single attraction. Of course, every author is well aware that every trip is a dynamic journey containing at least both a stay and two moves. Still this "stay-andmovement part of the travel" is seldom focused in the wider sense. Even books about tourism and sustainability often concentrate their examples on destinations or sites, not telling anything about how the tourists has travelled to these destination or how they are travelling back home.

The aim of this paper is to combine research of tourists' behaviour at sites or within destination areas with research based characteristics from the movement along the route itself. By doing so this author hopes that the readers could become more aware of the importance that routing behaviour has on other types of tourism behaviour - both at destinations and sites. The first discussion is based on some general models of regional systems, transportation and tourism systems. Later more specific models explaining tourism development and tourists' behaviour will be introduced.

This paper has at least four analytic dimensions:

- The history of routes in the tourism products.

- The diversification of routes into modes of travelling or thematic travel.

- The behaviour of travelling segments on the routes or at destinations based on the routes chosen for the trip.

- Strategies for future analysis of travellers and destination based on these findings will also be focused.

Before starting these analyses, a presentation of some models and theories based on the route dimension of tourism is needed, starting with the simple ones and then proceed to some more complicated. In the more descriptive analyses later in this paper, a return to these models is needed, sometimes supplied by new and more thematic models. 


\section{From "movement" to "surfaces" - from tracks to routes to destination areas}

17 To start describing what focusing on routes have meant to the development of tourism, going back to general geographical location models is important. During the sixties and seventies, Haggett (1965) completed a series of textbooks on "Models in Geography". His aim was to build a science of geography as opposed to the more descriptive stages of the subject. His illustration of stages in the analysis of a regional system, figure 1, could also be used to show the development of routes and regions in tourism. It is important to stress that even before tourism was regarded as a field of studies, transport and movements was examined by geographers like Haggett, some of those did also choose tourism as a subject for studies (in Scandinavia by Nordstrom \& Mårtenson, 1965; Sømme, 1965 \& 1970; elsewhere by Christaller, 1966).

Figure 1. Stages in the analysis of a regional system. Based on Haggett, 1965.
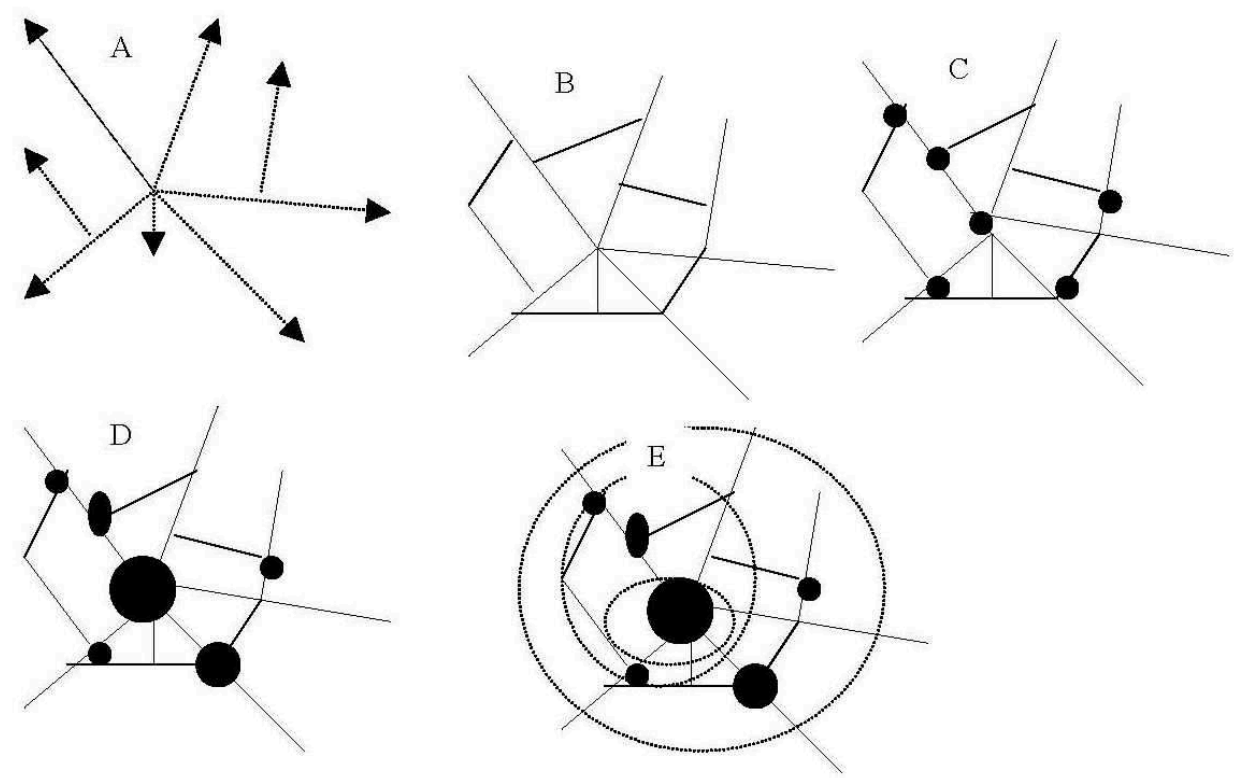

A MOVEMENTS B NETWORKS C NODES D HIERARCHIES E SURFACES

How could the general location model of figure 1 also be seen as a tool for tourism development analysis? The figure must then be regarded as describing stages in a process similar to the one in the Miossec (1976) model. Those stages are described as:

- Movements will be the first attempts of leaving the house, but mostly to return the same day or to the same site. The movements are not on a registered track or a sea route, but just described as a registration of where one has moved. Movements could also be described as discoveries, in the way Miossec (1976) shows.

- As soon as a route (or a track) has been used for more than a single organized trip, there will be a registration of a network. Such a registration will normally contain all the three basic elements of the Leiper model (figures 2 and 3). A network, however, will at this stage basically be viewed as the route in the Leiper model.

- When adding the destination region and the home to the Leiper models, stage $C$ in figure 1 shows a system of nodes with equal strength. Still the tourist development is only based on 
"home $\rightarrow$ route $\rightarrow$ destination and return", where each part of the trips is as important as the other.

- When some parts of a route either are visited longer than the others or has more visitors, a system of hierarchies is developed. Most route systems will be based on hierarchies, either as primary attractions (Leiper, 1990) to visit or as main destinations. But hierarchies might also be viewed as markets.

- The use of surfaces might be viewed as time zones from the homes or as price zones away from a tourism centre. Surfaces in this figure might also be viewed as zones of different markets: the inner zone as the reach of afternoon activities like evening skiing or cultural recreation; the next zone as a limit of week end travel and the outer as a holiday zone.

The stages of resort development in the Miossec model are:

- Discovery of the area

- Pioneer resort development starts

- Multiplication of resorts within a destination area

- Organization of the holiday space

- Hierarchical specialization or saturation

All the development stages of Miossec are also examined for: access or transport, tourism behaviour and attitudes. The later both viewed from the decision makers' and local population's points.

Though tourism has developed distinctive stages through stages, even Before Christ, tourism routes were well developed within both the Egyptian, Helenistic and Roman empires. Each stage of development could be found a couple of thousand years ago, and could be found when describing what has happened the last fifty years.

Butler's (1980) resort cycle model could also fit in here. But since this is only telling about a destination and not representing a travel-pattern model a further presentation must come later. Pryer (1997) has viewed the international en route tourists, especially those leaving the usual "highways" for new discoveries. He has set up some stages, mostly by focusing on the two initial ones:

- Discovery

- Following the footsteps of early pioneers

23 After this stage reporters take over by publishing travel handbooks and survival kits (Lonely Planet) and semi-organized tourism takes over from early travellers. Pryer (1997) is also segmenting the travellers into budget travellers and credit card travellers.

In accordance with the node development in Haggett's model, Pryer (1997) is quoting Vogt (1976) who identified an important aspect of the traveller culture as being the need of "gathering places" along the touring routes, mostly for the purpose of relaxation and socializing. These gathering places have later developed as travel centres. Such developments are taking different direction both due to segments of travellers visiting the site and due to the local adjustment to these travellers' needs. Four centres are identified by Pryer:

- Gateway reception centres

- Attraction reception centres

- "Freak centres"

- Traveller sanctuaries 
Many other centre types might be added, when describing travelling patterns of different segments.

\section{Tourism and travelling on routes as a dynamic Geographical System}

For a long time many attempts have been made of describing tourism as a system. Viewing travelling along routes is a dynamic approach to such descriptions. As a geographer I would like to start with "movement", starting from a place often called "home" and by some "market", or more correctly by Leiper (1979) called a "tourist generating region", and then showing the routes and destinations from the travellers point of view.

27 Leiper $(1979,1989)$ himself and many others have tried to reproduce the original model (figure 2) into new ones (figures 3 and 4). Others have tried to widen the content of the travel experience (figures 5 and 6 ).

Figure 2. The geographical elements of tourism - A.

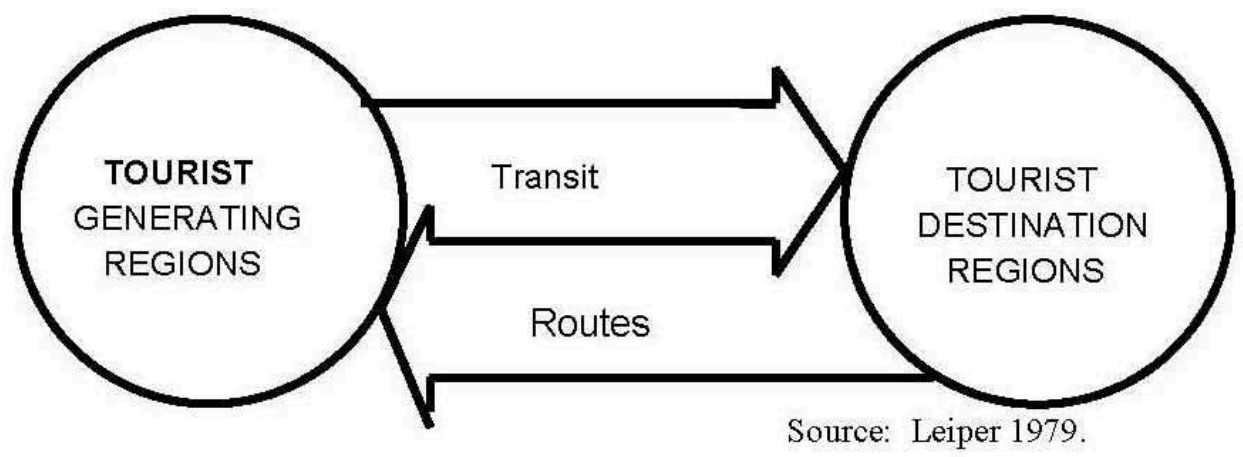

Figure 3. The geographical elements of a tourist system - B.

Transit region or route

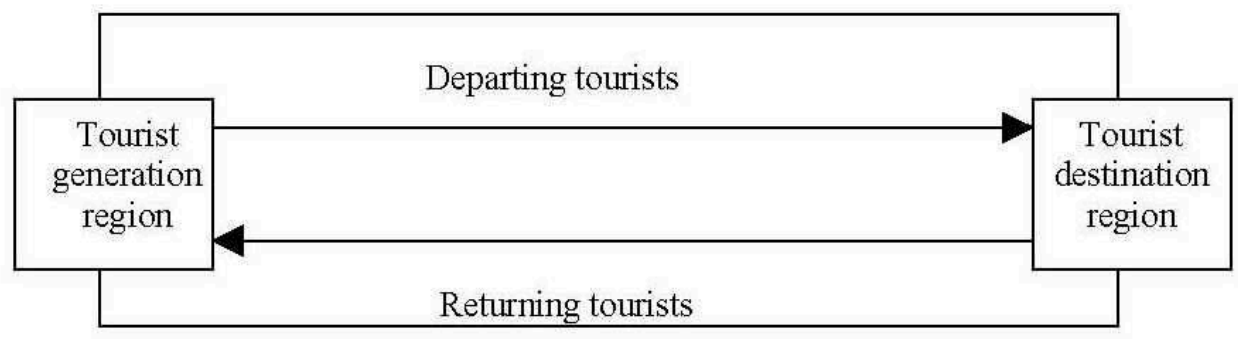

Transit region or route

Source: Leiper, 1989. 
Figure 4. The tourism system of Mill \& Morrison 1985.

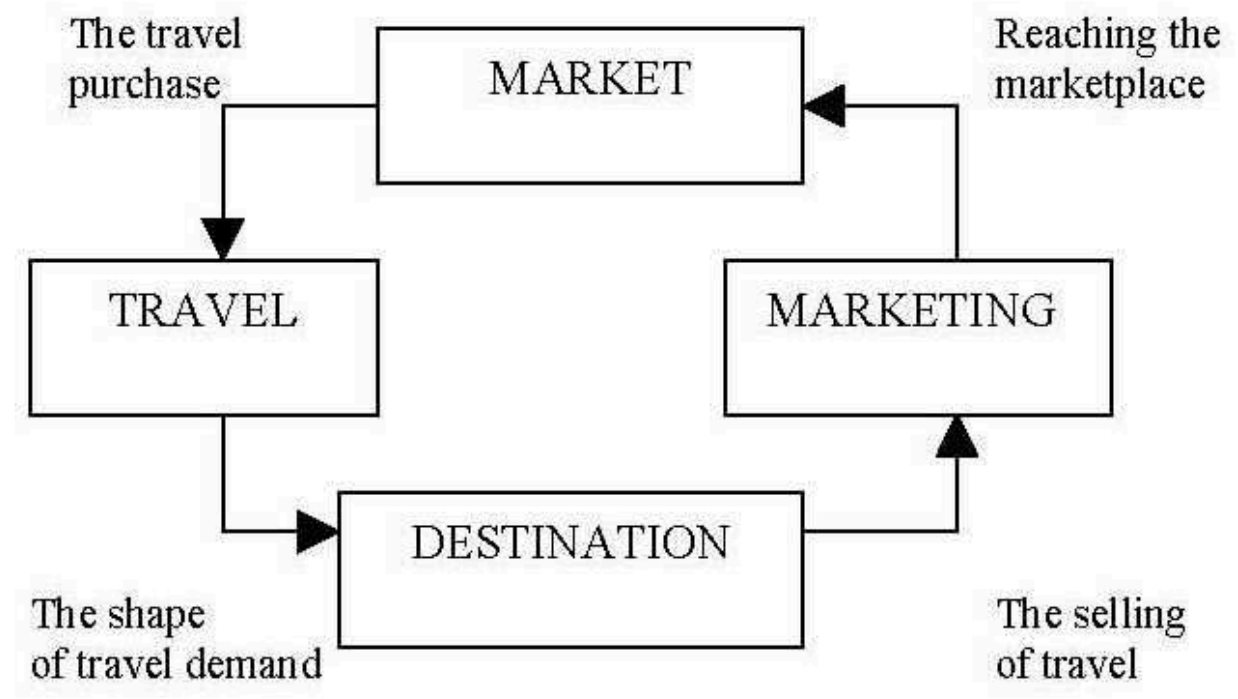

Figure 5. The Tourism Environment System.

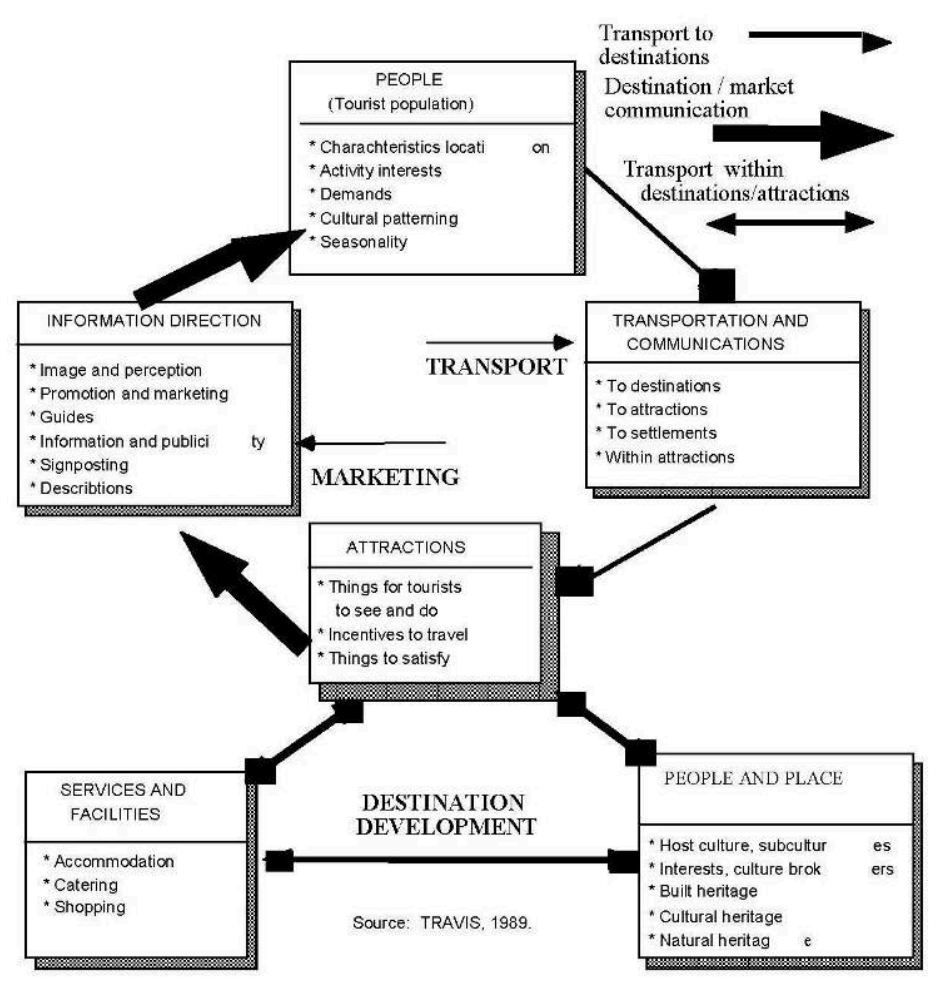


Figure 6. Destination area's perspective of a vacation experience.

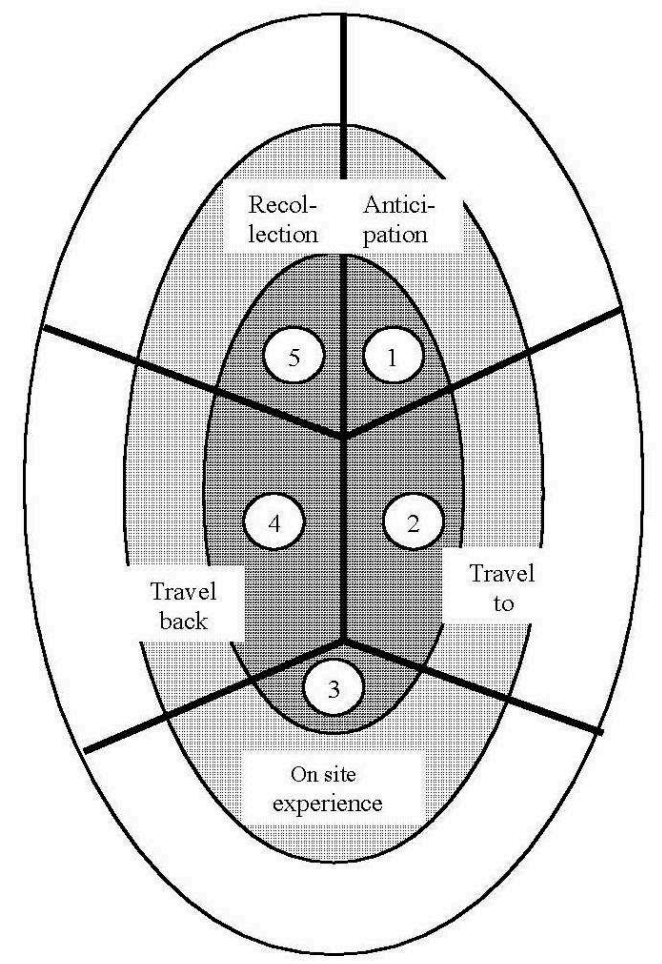

SOURCE: MURPHY, 1985

In his original article from 1979 Leiper points out that he has taken his elements partly from Gunn's (1972) "tourism environment". His description of each element is important since many authors later on are "quoting" this article. A long passage is therefore quoted here:

"A basic model of the geographic element is shown in Figure 2. The following discussion of roles and consequences of each geographical element in the system shows that the model can be developed beyond a representation of tourist flow patterns. It can serve as an analytical tool for describing the resources involved in the tourism process, in particular the industrialized resources. Moreover it facilitates delineation of areas of touristic impact.

Tourist generation regions can be defined as the permanent residential bases of tourists, the place where tours begin and end, and in particular those features of the region which incidentally cause or stimulate temporary outflow. This definition includes the basic geographical setting, together with the necessary behavioural factors pertaining to motivation. The existence and significance of "push" factors in tourist generation regions has been recognized in causal studies.

The generation region is the location of the basic market of the tourist industry, the source of potential tourism demand. Accordingly the major marketing functions of the tourist industry are conducted there: promotion, advertising, wholesaling, and retailing, underlying the marketing function is the question of why certain regions exhibit a tourist exodus, an issue with commercial and sociological relevance. There is correspondingly the matter of impact. What are the economic, social, and cultural effects in a community when a significant number of its members depart for tours into other regions?

Tourist destination regions can be defined as locations which attract tourists to stay temporarily, and in particular those features which inherently contribute to that attraction. In this context the attraction can be regarded as the anticipation by 
tourist of some qualitative characteristic, lacking in the tourist generation region, which the tourist wishes to experience personally. In a broader context, a definition of a tourist attraction would recognize that not all attractions draw tourists to a region: some are discovered en route.

Most tourism studies have been directed at the destination region. It is where the most significant and dramatic aspects occur. It is also the location of many parts of the tourist business: accommodation establishments, services, entertainment and recreational facilities.

Transit routes are paths linking tourist generating regions with tourist destination regions, along with tourists travel. They include stopover points which might be used for convenience or because of the existence of attractions. Transit routes are a vital element in the system. Their efficiency and characteristics influence the quality of access to particular destinations and accordingly they influence the size and direction of tourist flows. They are also a special case of tourism impacts, i.e., when changes arising from faster or longer haul transport cause stopover points to be bypassed. Transit routes are the location of the main transport component of the tourist industry." (Leiper, 1979, pp. 396-397).

Even though Leiper is showing that transit routes might include attraction stopovers too little efforts is made in showing the importance of the route itself. During the last two decades the development of thematic routes like "die Romatische Strasse", the Malt Whisky Trail, Scenic Routes, has been as an important element in travel as resort development. In the US this development started very early, the first Scenic Road came in 1913 (Lew, 1991). When adding boating, sailing, biking and trekking to the use of cars and coaches to move around, en route travel is not merely "transit".

In Norway, however, such official designated "tourist route road" status were not obtained by any road until the summer of 1998 when four National Tourist Roads were selected. They are the Hardanger Fjord road, the Sognefjell Mountain Road, the old Strynefjell road and the Coastal Road in Nordland county. All of these are situated close to our field study areas, and will be commented later as an information system.

1 Of course some roads have had an "unofficial name" presented in brochures, and sometimes even at road signs. Most of these were roads crossing the border between Norway and Sweden (the Blue Road, the Copper trail, etc.), but even some roads like the Atlantic road, the Golden route and the North Sea Road).

Leiper himself and others have later redrawn or extended the figure. In figure 3 the transit region or "the route environment" is more clearly defined, and the routes are indicated by direction lines. In this way the three main geographical elements are still shown:

- Tourist generation region or home, sometimes described as "market"

- Transit region or routes, sometimes described as "the travelling environment"

- Tourist destination region or sometimes described as destination and resort attractions.

3 This view has later been extended by many other authors, still the key elements will always be found! The next step might be to include further destination development first based on marketing or the transfer of information, later by including destination behaviour, and at the end - the aim of this paper - an extension to en route behaviour.

Some tourism development models are shown under the name of "the tourism system". The first textbook using that name was by Mill \& Morrison (1985). That book is mostly regarded as a marketing book, showing two "highways of communications":

- The awareness or marketing highway - where a destination tries to sell its image or products to a market 
- The transport highway - where tourist actually are on the route, trying to reach the destination. regarded as the core of the destination, just because they seem to be the reasons for visiting a "destination". The two other elements of the lower circle are "services and facilities" and "people and place". If we try to show the role of different producers or stakeholders in the Travis model, they might be:

- People - represented by the tourist population themselves. Often a trip is entirely produced by the travellers, but other producers might be "tour operators"

- Transporters - including both the travellers themselves (by own car or recreational vehicles) or different means of transport

- Marketing and information persons - and later this part should be viewed in-depth

- Destination developers - both including planers, governmental officials and investors

- Attraction managers - representing both commercial and non-commercial bodies. Regarding business travel, meeting places and conference venues are the "attractions".

- Service and facility providers - including a group of producers formerly regarded as "the tourist trade", the accommodation and catering sector. Shopping is also put in this block 
and at last:

- The regional human, culture and nature environment. of course, in many cases the nature environment is also the main attraction for the travellers, especially those visiting rented or own cottages.

This means that the Travis's model also functions well for describing who might be the stakeholders in a tourism development strategy. In Flognfeldt's extension of the Travis model (figure 5) the transport part is divided into "en route-transport" and "transport within the destination area". The latter is important, but was not directly communicated through Travis's original model.

If summing up, the development of Leiper-based models has moved from movements to transit route to transport, and the inclusion of "the highway of information" or "marketing message" is supposed to move in the opposite direction. My way of research will then be to examine if actual tourists on the route adjust their behaviour to fit these models or vice versa.

\section{The extended routes - the trip as a complete event}

The Leiper model could also be extended to a route system in another way, by viewing the "extended route" as a way of mapping trip behaviour. This is a tradition from the mid-sixties, from before the presentation by Leiper (1979). In a study mainly focusing on how to estimate the value of outdoor recreation, Clawson \& Knetsch (1965) described five stages of a trip. Their stages have been of great importance, and been used by several authors in different ways. The comments below of each stage are made by this author, and describe how field work data of Lillehammer students has been used in different analyses.

- Anticipation - including personal travel planning and advice from friends and relatives

- Travel to site - most of the actual trip, plus things that happens during this trip

- On-site experience - there might, of course, be more than one site to visit during a trip

- Travel back home - the rest of the actual trip

- Recollection - a process that never ends since memories of a specified trip is continuously changing often due to new travel experiences at other destinations.

There will most often be more than one site included in a trip. Travel to site might therefore be repeated, but there will only be one stage named "travel back home".

Murphy (1985) has put the stages of Clawson \& Knetsch into a more comprehensive model of development (figure 6). The model is separated into three ovals or descriptions. The outer part represent "the destination's (promotional) point of view", the middle part "tourists' point of view" and the inner part an "outdoor recreation experience model" as shown by Clawson \& Knetsch (1965). Such a view is very useful when examining both the destinations and the travelling patterns.
1. Accumulation of mental images about vacation experiences
2. Modification of those images by further information
3. Decision to take a vacation trip
4. Travel to destination
5. Participation at the destination 


\section{Return home \\ 7. Modification of images based on the vacation experience}

(Source: Murphy 1985)

By transferring Gunn's (1998) phases 1, 2 and 7 into the Murphy model they could all be seen as destination image formation phases. If all these models should be transformed to a situation of interviewing tourists, figure 7 shows some differences based on where and when the interviews take place. One of the great challenges would be to use the different trip stages in marketing and information strategies.

Figure 7. Stages during the extended trip.

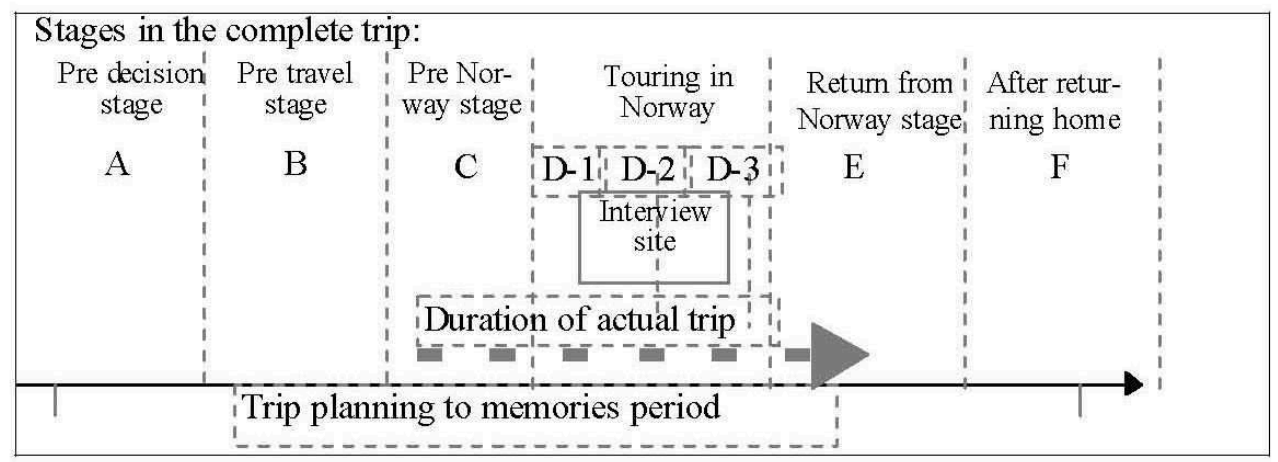

SOURCE: FLOgNFELDT \& ONSHUS, 1998

\section{How can the "tourism systems" knowledge be used in a data collection process?}

In the paper quoted in the beginning of this paper, Fridgen (1984) discussed every stage in the Clawson \& Knetsch model. Fridgen both explained the lack of research based on the whole trip and on the transportation stages and asked for further research. In his discussion of elements in the Travel to Destination stage, Fridgen tells:

"Transit regions and destinations are competitive. The challenge for the transit region is to attract and hold tourists. The built environment is one medium used by a community to express itself, to inform travellers about its attractions and hospitality. Little is known about how empathy and curiosity are elicited in travellers as they encounter a community".

For many repeating visitors to Norway, especially form Germany and the Netherlands, a pattern like this seems to be common:

"The first visit to Norway is a substantially long trip - duration 3 - 5 weeks including either the Western Fjords, the Lofoten islands or the North Cape. The next trip is a regional one, giving possibilities of longer stay at certain destinations and shorter day stages. If they continue to visit Norway, one or a few sites previously visited are chosen as an accommodation base." (Flognfeldt, 2000a)

Fridgen (1984) was also discussing the directional effects - is there a difference of how tourists view an area on the road to a destination, compared with what they view on the return back. He found no differences when viewing the beauty (of landscapes, nature and villages). 


\section{knowledge about all travel expenditures. Examples of such stages might be:}

A. Pre decision stage. The expenditures of this stage are connected to the decision making process - maps, travel handbooks and other information material are the prime ones. As soon as the decision seems to be close, also some medicare expenditures like brushing up vaccinations, could be added to the "pre-paid expenses".

B. Pre travel stage. The route or destination or at least the country to visit - is now chosen. Most expenditures are to pay for whole packages, or tickets, insurance and other parts of the trip. In addition clothing, sport gear, handbooks, film and medicines will complete this stage of expenditures. Some could be payments for services at the destination, others for transport to and from the destination and others are affiliated to take a trip without regards to where this trip will go.

C. Trip to main destination stage (Norway). In our case trips (for foreigners) from the respondents home address to Norway. Since Scandinavia until this year has been an "insular peninsula", most foreign visitors must use either car ferries, train ferries or aircraft to enter the area.

D. Touring in Norway. In our case shall this be separated into three sub-stages:

E. D-1 On tour, before the interview takes place.

F. D-2 At interview site.

G. D-3 On tour, after interview took place.

H. Returning home from Norway stage.

I. After returning home - memories. The most focused part of this is film processing.

For Norwegian respondents, stages D-1 and D-3 are substitutes for stages $\mathrm{C}$ and $\mathrm{E}$.

This list of possible stages (and at the same time of geographical areas) during the extended trip should be supplied by a list of possible ways of collecting information or the geographical areas where this collection might take place. Revised models might therefore be drawn to show the accurate stages of each data collection process.

The model of figure 7 might be extended for use in the analysis of tourists' consumption. The "anticipation stage" of Clawson \& Knetsch is divided into two stages:

- Pre decision

- Pre travel 
For many practical uses such a division is important, i.e., when studying the response to different travelling information media (Flognfeldt \& Nordgreen, 1999) or on consumption patterns (Flognfeldt, 2000).

\section{Segmenting tourists by modes of travel}

An important question has emerged during the ten years of field work data collecting and analysis of en route behaviour: which types of segments could better be used for explaining en route behaviour? The tradition in Norway, as elsewhere, has exclusively been to focus on nationalities for explaining travel behaviour. Expressions like: "The German do like this, opposed to tourists from the US who act like...", seem to be widely used, even among professional market analysts. Experiences from field studies and tourism planning show that the nationality stereotypes often presented by marketers should not always be accepted as scientific without a further examination that includes tests of other segments. The task must therefore be to test other types of segments, in addition to nationality, such as modes of travel, use of transport, accommodation and some socio-demographic variables.

"Modes of travel" was tested in the first fieldwork (Flognfeldt, $1992 \mathrm{a} \& \mathrm{~b}$ ). The origin was a model presented in Pearce (1987) based on Campbell (1966), that I thought could be interesting to use. Oppermann (1995) has been thinking in the same way by showing some models of tourism flow patterns. Figure 8 has to be explained a bit further.

Figure 8. Modes of travel according to the modified Campbell/Flognfeldt model of 1999.

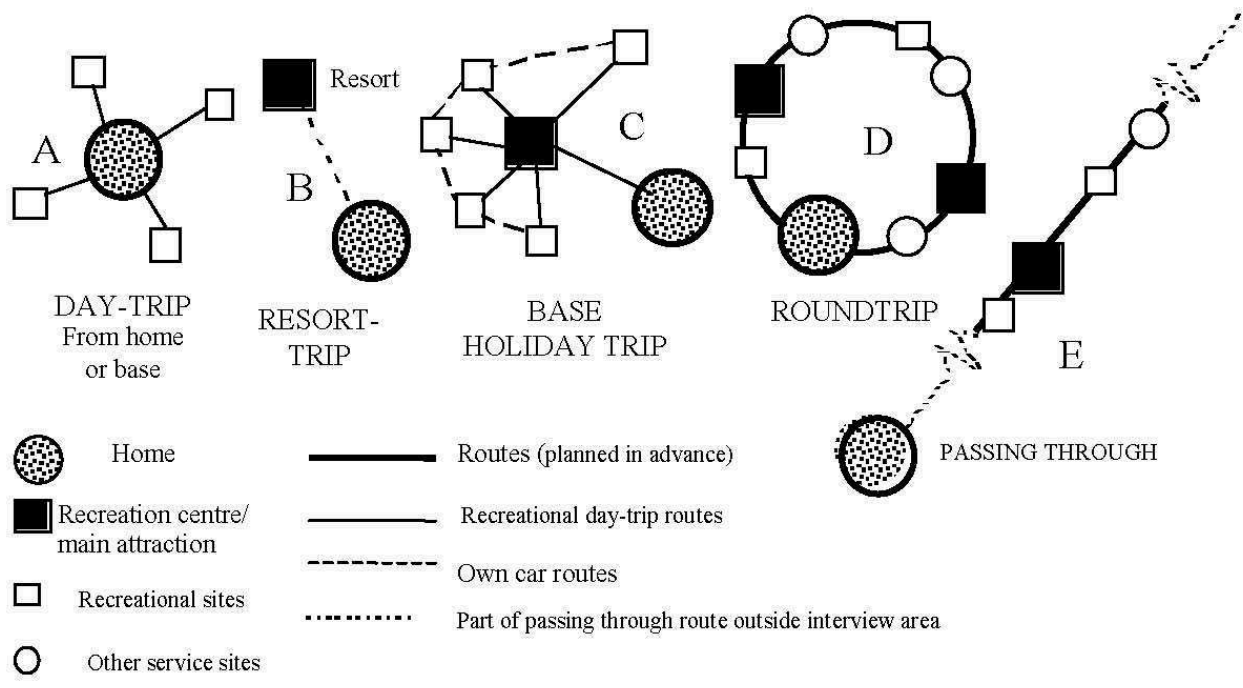

61 Another of the methods of analysis was to look at the patterns of travelling to and through the region by geographical space and time models - like the one describing tour operated trips. Another is to focus on a series of different segments often described as modes of travelling.

This segmentation is based on the Campbell model (1966) - but reversed. Descriptions of trips according to modes of travelling:

- Day trips - trips starting and finishing at home during the same day. As visitors they must be described as short time guests. Some times day trips are called "excursions" 
- Resort trips - trips to a place where the major part of the stay is at the accommodation location. These guest are those often favoured by marketing efforts - the reasons might be the belief that the longer stay in the region, the more profitable those guests are for the area. In some studies resorts are extended to "destination areas".

- Base holiday trips - the prime trip is going from home to a single accommodation unit with a longer stay than three nights. These visitors do take some day trips out of the accommodation area, i. e. to visit attractions, in addition to using on site attractions.

- This group of travellers should have been split into two: those staying at a base in the field area and those staying outside. Only the latter group is focused in this paper since they will be short time guests. The bases differ from destination areas by the actual travel behaviour found during the visits.

- Tour operated round trips - mainly by coaches - where the travellers are visiting new places every day and night. A few of those trips are based on combining railroads and local scheduled bus routes. These groups are very often staying for a very short time, either visiting an attraction during day time or just to get a nights' sleep in a local hotel.

- Round trips by private cars or recreation vehicles - are in principle organized as the tour operated ones, but those driving in private cars have a bigger freedom of individual choice during the trips. Some round trippers stay at the same site for a couple of days, others are just passing through.

The intention of the Campbell model was to examine modes of recreation travel. When regarding the modes of travel patterns from the point of view of the local tourism industry, also other modes of travel have to be included: in most studies, business travel and travel related to work or organizations therefore have to be added to the "Campbell modes of travel model" as important segments.

Not all parts of the travel experiences will take place at the area of accommodation. In Norway, types of base experiences may take place at a substantial distance away from the accommodation bases. For middle of the day visitors to Røros we traced bases up to $250 \mathrm{kms}$ away, telling that the day trips had a length of up to $500 \mathrm{kms}$ plus a $4-6$ hours stay at the attraction. Similar distances are measured for alpine ski resorts (Hafjell, Trysil, Hovden, Oppdal and Hemsedal) and theme parks like Hunderfossen Family Park.

Two different travelling distances or day trip fields are described in figure 9:

- Visitor fields - indicating how far away from a base area might an experience take place if the visitors should be able to return to their base the same day

- Attraction fields - indicating how long distance are day trippers will to go to an attraction and returning back the same day

Figure 9. Day trip commuting fields.

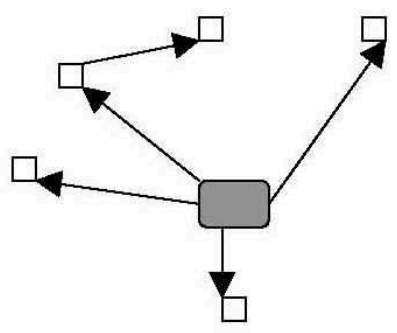

Visitor field-out from base

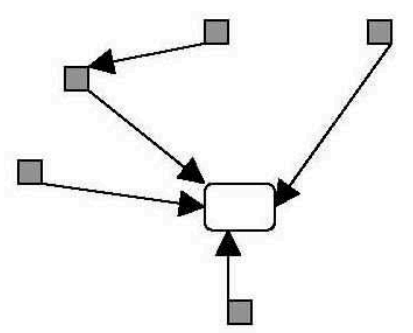

Attraction field - in to attraction
Accomodation base

Attraction site

Acceptable distance

to travel 
Both these distances are of high importance to those marketing accommodation areas.

The most usual way of segmenting travel is to use business and pleasure travel as the two different ones. This author has shown a way of segmenting travel according to when travel happens and who is paying for the trip - see figure 10.

Figure 10 has three dimensions: Work <-> leisure; who is paying for the trip and education travel. Flognfeldt (1979) includes five different types of travel based on these dimensions:

- Holiday and leisure

- Travel and commuting to/from work

- Incentive travel

- Business travel

- Seminars and conferences

Figure 10. Segmenting according to work<->leisure and who is paying the trip.

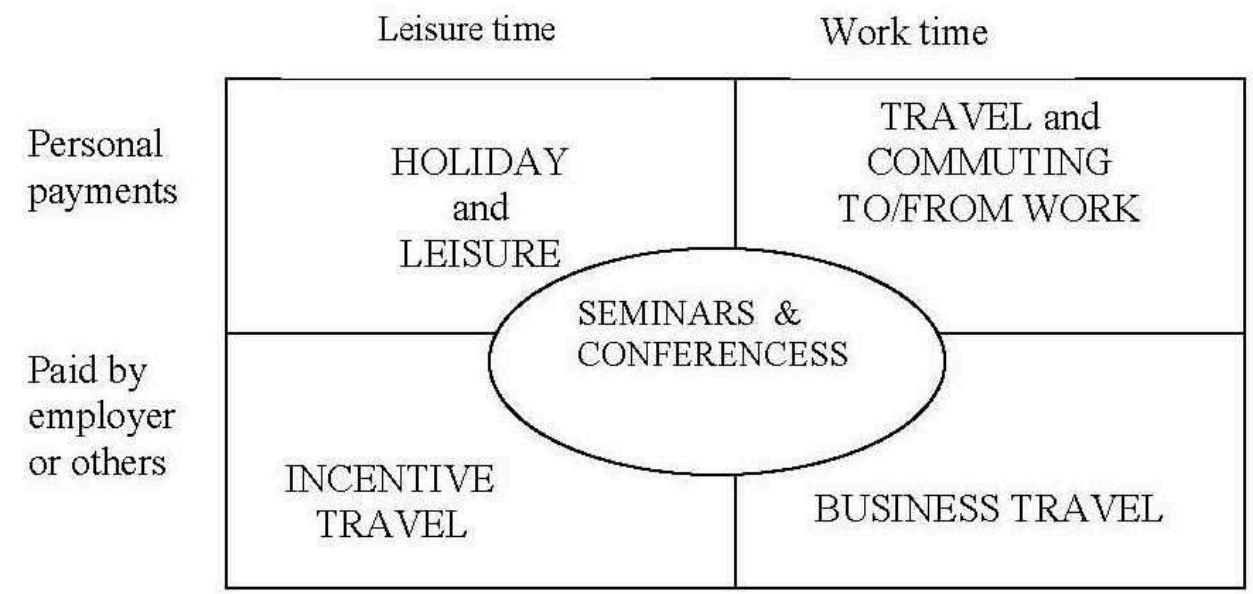

SOURCE: FLOgNFELDT, 1979

When looking at which type of accommodation a person is supposed to use, just examining his socio-demographic status might be lacking important information, like: "who is paying for this trip?". The use of attractions will be different when an incentive traveller is visiting a resort compared to a business traveller, even if both travellers are paid by their employers. At a Saturday night train returning from the rural parts of Norway to Oslo, a group having used their second home for skiing and a commuter going for work on a road construction, will be on different trips.

What if the view should be turned - and seen from the local area? Another way of using the modified Campbell/Flognfeldt model is to view different groups of tourists from the way they are using a single site. This is shown in figure 10 where the point of view is from the destination area. In this way the local perception of travelling segments is another than the one regarding the whole trip. At least five different travelling patterns "hit" this model region.

The model of figure 11 shows a very common structure of such mountain municipalities in Norway that are highly dependent on tourism. The model originates from studies of alpine ski resorts in mountain valleys. The service centre, which often also is the administrative centre of the municipality, is located down in the valley. In 
addition one ski resort or more are located further uphill due to better snow conditions. There will often be a competition between these two types of centres, especially on service provision and shopping possibilities (Flognfeldt, 1999 a).

Figure 11. Patterns of tourism travel - viewed from a local focus.

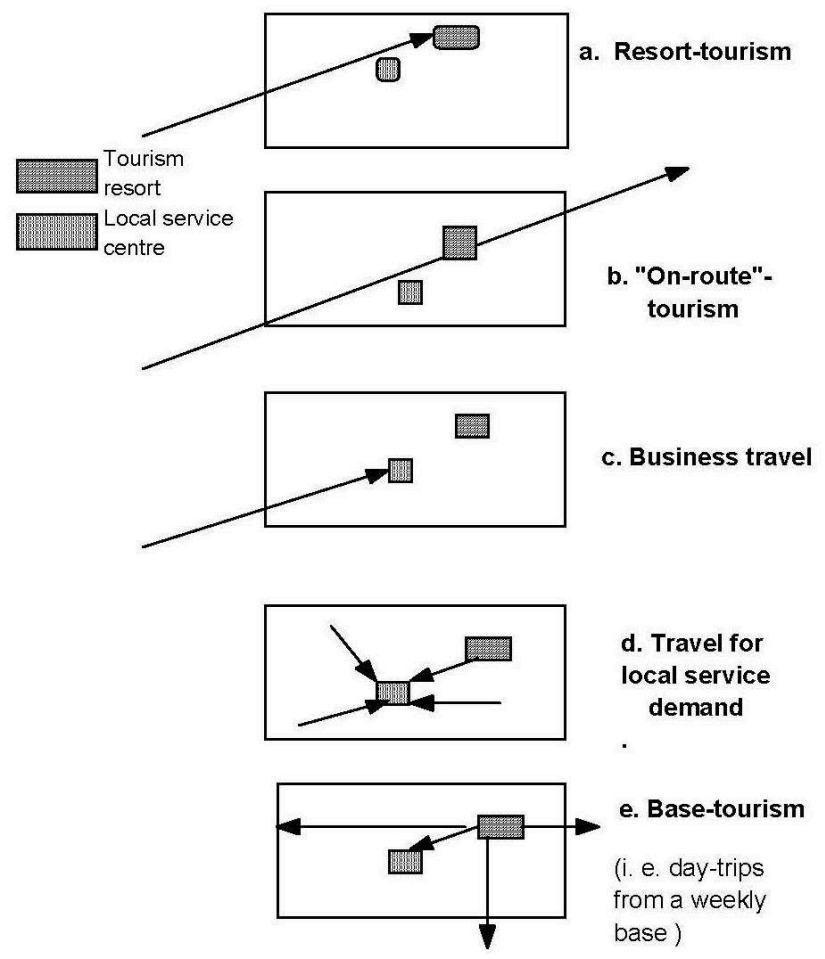

SOURCE: FLOgNFELDT, 1995 A

The model indicates five different travelling patterns named after the most common segments using the pattern:

- Resort tourism - where city tourism could be included by drawing the service centre and the resort functions (e.g. RBD) close to each other

- En route tourists - either just passing through or choosing a short stop-over

- Business travel, among others including:

- Salesmen

- Administrators

- Service workers

- Travel for local service demand

- Base tourism

74 Especially when planning service provision to an area this model seems very useful. In addition segmentation based on the actual behaviour of the respondents has been tested, like:

- Use of accommodation the night before interview

- Use of modes of transport to reach the site of interview

- Number of previous visits to the area, including those previously having lived permanently in the area

- Trip index groups 
Also a set of socio-demographic and psychographic descriptors will later in a later extended version of this paper be tested as segmentation tools. They seem very good in studies of attraction behaviour along the tourism routes.

\section{Time geography models}

76 The tradition of using time geography models introduced by Hägerstrand (1974 and 1978 a \& b) in the early seventies. One of the aims of using such models was to look closer at how different segments of travellers (mostly daily commuters) used different modes of transport between home and office and activities (Mårtensson, 1978).

77 A very specific result of these studies was the introduction of the system of "flexible working hours" in Stockholm, Sweden. This innovation was later on adapted in many other environments resulting in a much more efficient use of transport.

Such time geography models were used in studies of local recreation travel behaviour, but in this author's knowledge, not in any tourism travel behaviour study according to this author's knowledge?

Why are then so few time-geography models used in tourism analyses? One reason might be that the bulk of time geography studies took place in the Seventies, some time before the studies of tourism really took off. Another must be that geographers and others have not been that interested in the dynamics of travel as Fridgen (1984) also has shown for psychologists. Studies taking place at a single resort or a regional level have had the priorities.

80 An attempt of showing three different time geography patterns of travel within a single day is described in figure 11 above.

81 Figure 12 shows the standardized geographic pattern of a day on a tour operated trip. Other figures are constructed to show a typical day trip and a similar day at a resort or an attraction type theme park. 
Figure 12. Standardized pattern for a single days trip on a tour operated coach trip visiting a single and very attractive museum - like Maihaugen Open-air museum in Lillehammer or Lom Stave Church.

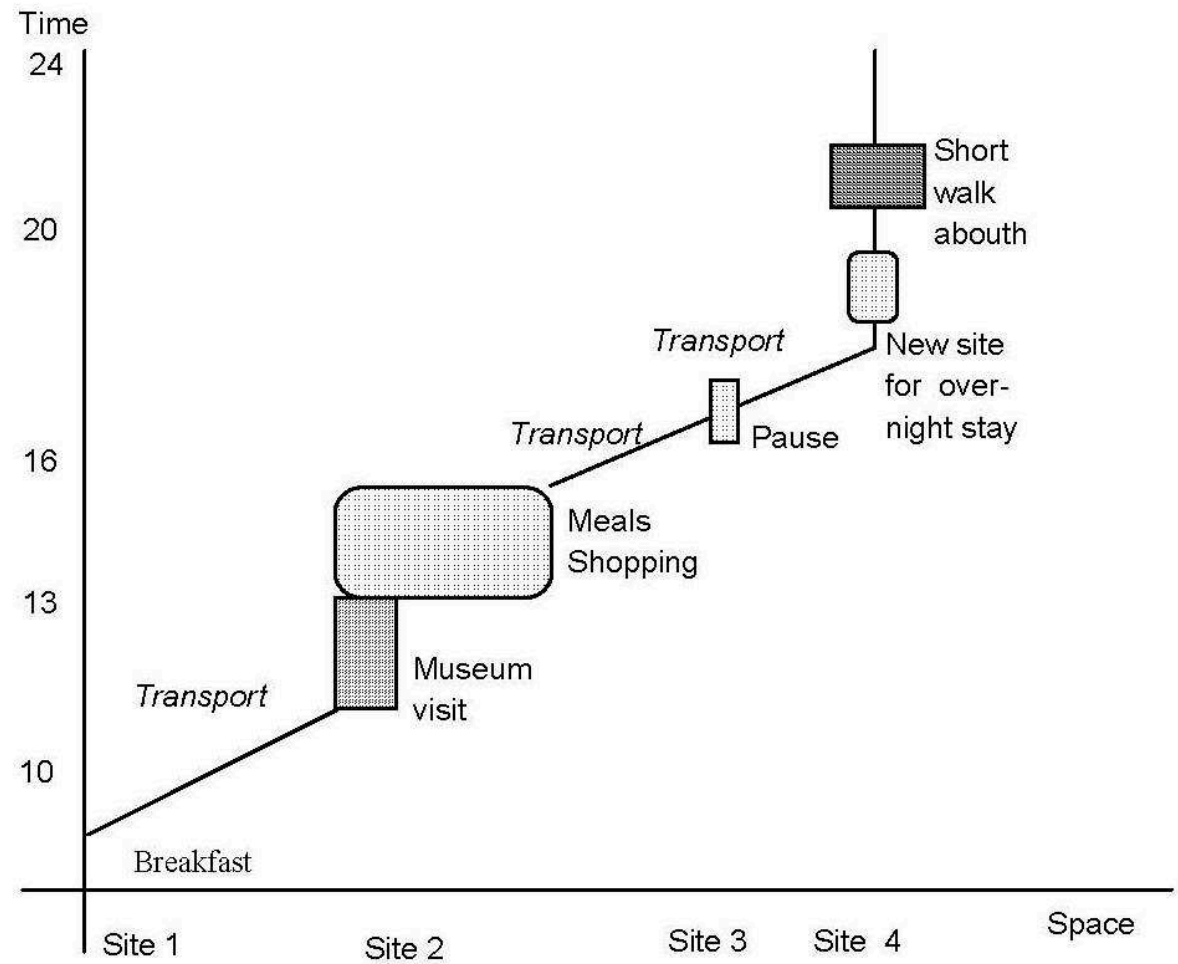

When trying to generalize these different time geography based travelling patterns into a model of potential site visitation, figure 13 shows an example model used by Flognfeldt (1999) to describe and analyze traffic patterns in the municipality of Lom in the Jotunheimen mountains of Norway.

Figure 13. How sites are located into different routes.

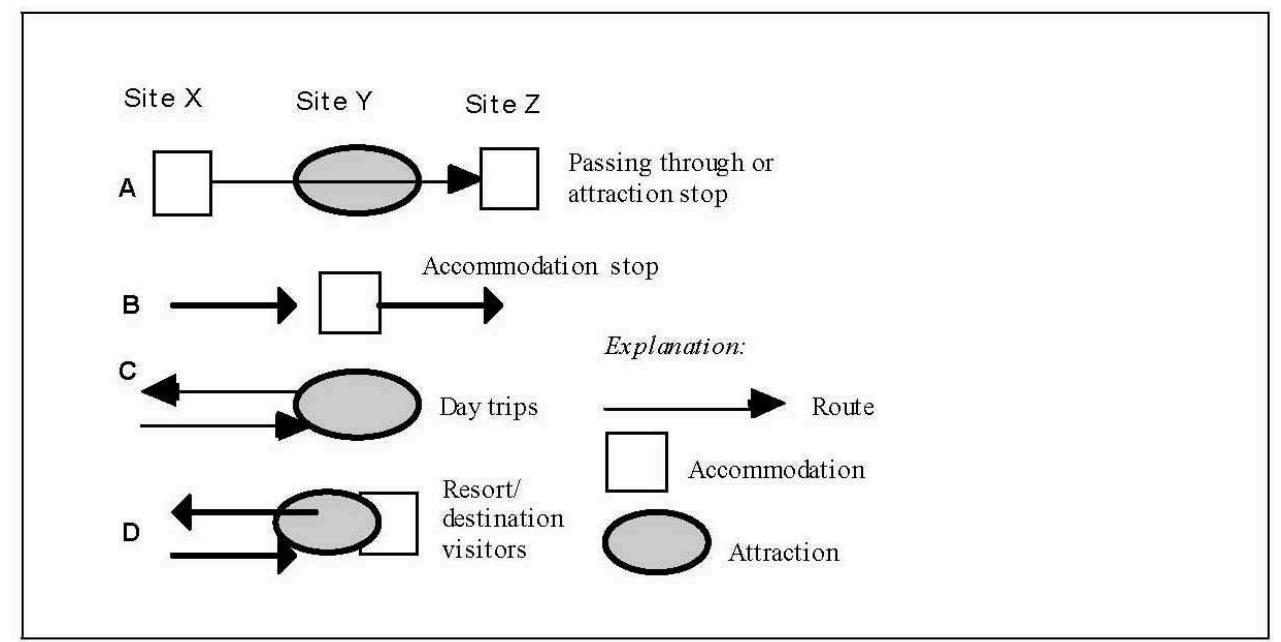

Travellers belonging to each of the four different visitor patterns described in figure 13 have very different behaviour both on attraction visitation and expenditures. Those on a pattern A trip are much more frequent attraction visitors than those on pattern B. 
This is seldom understood by local tourism promoters, since their main focus is to attract overnight stayers. Since short time stoppers (persons staying less than one night) are not registered in most statistics, their behaviour is under-focused in most consumption studies and other studies based on accommodation statistics.

Most often short time visitors are completely neglected as customers in such studies. When trying to combine economic studies based on expenditures with those based on the income of firms belonging to the tourism trade, this lack of measuring short time stoppers might be one of the reasons why there is a discrepancy between the two methods (Onshus, 1997).

A. Tourist that are visiting site $Y$ just during daytime

B. Tourist that are just staying overnight at site $Y$

C. Tourists that are just going to visit site $Y$ on a day-trip from home or holiday base

D. Tourist that are choosing site $\mathrm{Y}$ as a destination/resort for more than one night's stay

Flognfeldt (1999) presented a survey conducted in Ottadalen 1995. On of his hypotheses was that those interviewed at a site between 1200 and 1700 hours were more likely to have been visiting a museum at the spot they were interviewed, than those interviewed later that night at an accommodation site. The latter, however, could have been museum visitors that same day - at another site.

Thus both where an interview takes place and when is of high importance to the results of both consumption and attraction use studies.

Figure 14 shows the travel pattern registered in Ottadalen 1995. This region has a variety of nature and culture attractions. Many nature attractions are primary according to Leiper (1990), but only one cultural attraction is so. This is Lom Stave Church, a more that 900 years old church still in use for the local congregation. Lom is therefore a site to be visited by all four categories shown in figure 13 .

Figure 14. Ottadalen 1995 Modes of travelling measured for 2368 respondents.

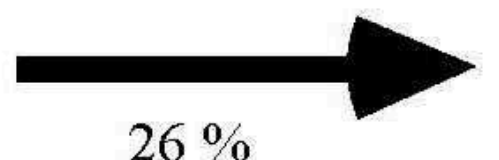

Ottadalen is the main destination

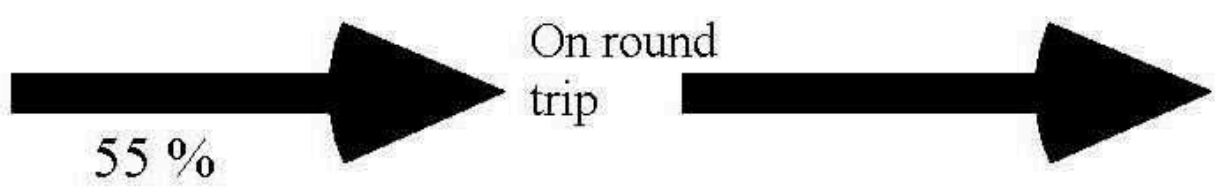

$13 \% \quad$ Passing through

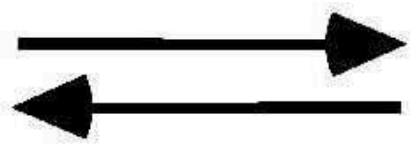

$$
\begin{array}{ll}
6 \% & \begin{array}{l}
\text { Day } \\
\text { visitors }
\end{array}
\end{array}
$$


Figure 15. Population mobility in space and time.

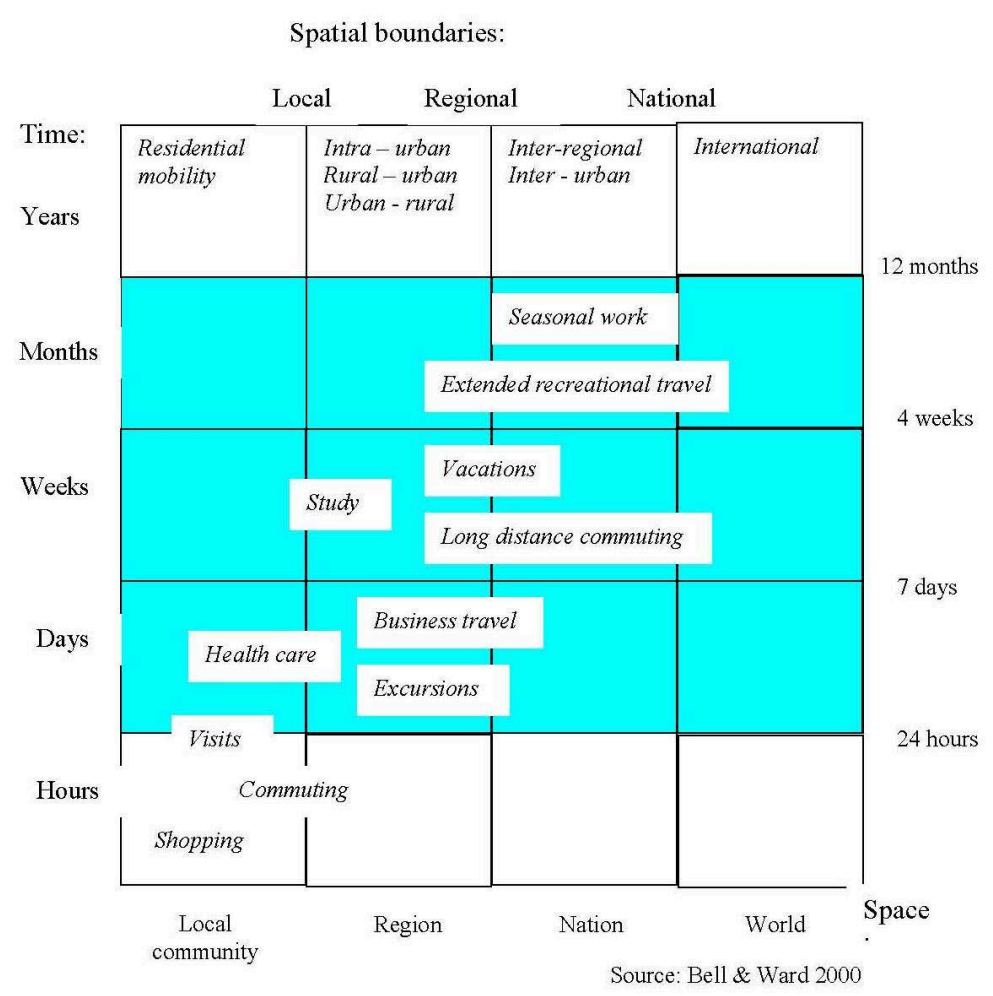

When does a long lasting tourism trip become a part of a migration process instead? Bell \& Ward (2000) has shown how a time and space diagram could be used to show different types of travel. Most types of movement in time and space are included in that model. Most forms of tourism are found on the shadowed part of the figure, with a duration between a day and a year.

This figure allows a much further discussion of time and space dimensions, both in tourism and other types of travel.

Measuring en route behaviour at a short stop site or for a wider destination area might also be done by using the trip index (Flognfeldt, 2000). One problem by using the trip index might be when the data collection is restricted to interviews at accommodation units.

\section{BIBLIOGRAPHY}

BELL M. \& WARD G. (2000), “Comparing temporary mobility with permanent migration”, Tourism Geographies, 2, 1, pp 87-107.

BUTLER R. W. (1980), “The concept of a tourist area cycle of evolution: implications for management of resources”, Canadian Geographer, 24, 1, pp. 5-12. 
CAMPBELL C. K. (1967), An approach to research in recreation geography, BC Occasional Papers No 7, 1967, Department of Geography, University of British Columbia, Vancouver, Canada.

CARLSTEIN T. POUKES D. \& THRIFT N. (1978), Human Activities and Time Geography, Edward Arnold, London.

CHRISTALLER W (1963), "Some considerations of tourism location in Europe: the peripheral regions - underdeveloped countries - recreation areas", Regional Sciences Association Papers, 12, pp. 95-105.

CLAWSON M. \& KNETSCH J. L. (1966), Economics of Outdoor Recreation, John Hopkins Press, Baltimore, USA.

DELBAERE R. (1994), La route du textile dans le Hainaut occidental belge, Paper presented at Conference on Geography of Tourism, Oppland College, Lillehammer.

DEWAILLY J.-M. (1998), “Images of Heritage in Rural regions”, in BUTLER R., HALL C. M. \& JENKINS J. (1998), Tourism and Recreation in Rural Areas, Wiley, Chichester, UK.

FLOGNFELDT T. (1979) "Noen refleksjoner omkring begrepet 'reiseliv",, ("Some reflections about the concept of 'travel and tourism'"), Plan og arbeid, no. 3, 1979.

FLOGNFELDT T. (1995a), Areal, sted og reiserute (Area, site or route), Fagbokforlaget, Bergen, Norway.

FLOGNFELDT T. (1995 b), Reiselivsgeografi (Tourism Geography), Universitetsforlaget, Oslo, Norway.

FLOGNFELDT T. (1997a), “Eco-Tourism in remote areas of Norway - just a green veneer?”, Paper presented at the ISMR XIII in Maynooth, Ireland 1995 and published in BYRON R., WALSH J. \& BREATHNACHT P. (1997), Sustainable Development on the North Atlantic Margin, Ashgate, UK.

FLOGNFELDT T. (1997b) “Cultural Attractions along the Tourist Routes”, Paper presented at the Trails in the Third Millenium Conference, Cromwell, Otago, New Zealand. Proceedings edited by Higham \& Kearsley.

FLOGNFELDT T. (1998), Dombås - $i$ vegen? (Dombås - in the road?), Working paper 60/98, Lillehammer College.

FLOGNFELDT T. (1999 a), Trysil-prosjektet, Konsekvens- og mulighetsanalyse av en foreslått utbygging $i$ Trysilfjellet for strekingen Innbygda - Nybergsund (The Trysil Project, A feasibility analysis for the areas of Innbygda and Nybergsund based inn a proposed Master Plan for developing the Trysilfjell area), Working paper no 86/1999, Lillehammer College.

FLOGNFELDT T. (1999 b), "Impacts from the short time visitors to local communities in the mountain areas of Southern Norway", The International Journal of Tourism Research, 1, 5, pp. 359-373.

FLOGNFELDT T. (2000 a), Reisendes oppholdstid på et sted. En refleksjon over bruk av oppholdskvoter som mål på et steds betydning i reiseruta (The travellers stay at a site - a reflection of the usage of trip index to measure the importance of a site in the complete route), Research report no. 55/2000, Lillehammer College.

FLOGNFELDT T. (2000 b), “Destination aesthetics along tourism routes. Architects' and tourists' perception of a site", in UMBELINO J. (coord.), Sustainable tourism, Centro de Estudos de Geografia e Planeamento Regional, Serie Estudos, No 3, Lisboa, Portugal.

FLOGNFELDT T. (2001), Developing new tourism products in the "Primary attraction shadow", Paper presented at the $3^{\text {rd }}$ European TTRA Conference, Kiruna Sweden, Later revised for presentation in Dubrovnik, Croatia, 2002. 
FLOGNFELDT T. \& ONSHUS T. (1996), Reiselivsundersøkelsen i Ottadalen 1995, Rapport nr. 1. Data om de tilreisendes forbruk målt i Ottadalen juni- september 1995 (The Tourism Study at Ottadalen 1995, Report no. 1, Consumption), Working paper no 35/1996, Lillehammer College.

FLOGNFELDT T. \& ONSHUS T. (1998), Measuring tourism expenditures - methods and limitations, Paper presented at the IGU Study Group on the Geography of Sustainable Tourism Conference in Estoril, Portugal, August 1998, Revised 2000.

FLOGNFELDT T. \& NORDGREEN R. (1999), Information used for temporary stop decision-making along tourist routes in Norway, TTRA Annual Conference Proceedings.

FORFANG H. G. (1976), The cultural tourists in Norway during the $19^{\text {th }}$ Century, Lecture at Oppland College (not published lecture notes in Norwegian).

FRIDGEN J. D. (1984), “Environmental Psychology and Tourism”, Annals of Tourism research, 11, pp. 19-39.

GUNN C. A. (1972), Vacationscape, Designing Tourist Regions, University of Texas, Austin, Later editions also included.

HAGGETT P. (1965), Locational Analysis in Human Geography, Edw. Arnold Ltd., London, UK.

HALL C. M. (1995), Introduction to tourism in Australia, Second edition, Longman, South Melbourne, Australia.

HALL C. M. (2000), Tourism planning. Policies, Processes and Relationships, Prentice Hall, Sydney, Australia.

HÄGERSTRAND T. (1974), Orter i regional samverkan (Places in regional cooperation), Statens offentliga utredningar (SOU, 1974-2), Allmänna förlaget, Stockholm, Sweden.

HÄGERSTRAND T. (1978 a), "Survival and Arena”, in CARLSTEIN T., POUKES D. \& THRIFT N. (1978), Human Activities and Time Geography, Edward Arnold, London.

HÄGERSTRAND T. (1978 b), “A Note of the Quality of Life-Times”, in CARLSTEIN T., POUKES D. \& THRIFT N. (1978), Human Activities and Time Geography, Edward Arnold, London.

KLEIVEN J. (2001), Praktisk bruk av Lillehammer-skalaene (Practical use of the Lillehammer scales), Working paper no. 121/2001, Lillehammer College.

LEES J. A. \& CLUTTERBUCK W. J. (1882), Three in Norway (From Norwegian edition 1967, Tre i Norge - ved to av dem. Tanum), Oslo.

LEIPER N. (1979), “The Framework of Tourism. Towards a Definition of Tourism, Tourist and the Tourism Industry", Annals of Tourism Research, 6, 2.

LEIPER N. (1989), Tourism and Tourism Systems, Occasional Paper No.1, Department of Management Systems, Massey University, Palmerston North, New Zealand.

LEIPER N. (1990), “Tourism Attraction Systems”, Annals of Tourism Research, 17, pp. 367-384.

LEW A. (1991), "Scenic Roads and Rural Development in the US”, Tourism Recreation Research, 16, 2 , pp. 23-30.

MAIER J. LUDWIG J. \& HERGEL L. (1994), The impact of museums on the economic and cultural development in Upper Franconia, Bavaria, Paper presented at Conference on Geography of Tourism, Oppland College, Lillehammer.

MILL R. C. \& MORRISON A. M. (1985), The Tourism System: An Introductory Text, Prentice-Hall International, Englewood Cliffs, US. 
MIOSSEC (1976), "Eléments pour une Theorie de l'espace touristique", from PEARCE D. (1988), Les Cahiers du Tourisme, Aix-en-Provence, France.

MYRPHY P. (1985), Tourism - a Community Approach, Methuen, London, UK.

MÅRTENSSON S. (1978), “Time Allocation and Daily Living Conditions”, in CARLSTEIN T., POUKES

D. \& THRIFT N. (1978), Human Activities and Time Geography, Edward Arnold, London.

NORDSTRÖM O. \& MÅRTENSSON S. (1965), Turismen på öland, Department of Geography, University of Lund, Sweden.

ONSHUS T. (1997), Sommerturistenes forbruk. Hvem var høyforbrukerne i Ottadalen 1995? (The consumption of Summer tourists. Who were the high spenders in the Ottadalen valley 1995?), Unpublished Master Thesis, Buskerud College, Hønefoss/Lillehammer College.

OPPERMANN N. (1995), “A Model of Travel Itineraries”, Journal of Travel Research, 33, 4.

PEARCE D. (1987), Tourism Today: a geographical analysis, Longman Scientific \& Technical, Essex, UK.

PEARCE D. G. \& ELLIOTT J. M. C. (1983), “The Trip Index”, Journal of Travel Research, 22, 1.

PRYER M. (1997), “The Traveller as a Destination Pioneer”, Progress in Tourism and Hospitality Research, 3, pp. 225-237.

RITCHIE J. R. B. \& GOELDNER C. R. (1994), Travel, Tourism and Hospitality Research.A Handbook for Managers and Researchers, Second Edition, Wiley, NY, USA.

SKAARUD B. (1996), Analyse av den individuelle dagsturisten til Ottadalen (fra Valdres og Gudbrandsdalen) med innslag av strategiske elementer (An analysis of the individual day-trippers to the Ottadal valley), Diploma Thesis in Tourism, Lillehammer College.

SøMME A. (1965), Fjellbygd og feriefjell (Mountain Community and Holiday Mountains), Ad Novas, Cappelen, Oslo, Norway.

SøMME A. (1970), Fritid og feriemiljø (Leisure and holiday environment), Ad Novas no. 8, Universitetsforlaget, Oslo, Norway.

THUROT J. M. (1980), Le Tourisme tropical balnéaire: le modèle caraibe et ses extensions, Thèse, Centre d'Etudes du Tourisme, Aix-en-Provence, France, from PEARCE (1987).

TOWNER R. (1996), A historical Geography of Recreation and Tourism in the Western World 1540-1940, Wiley, New York.

TRAVIS A. S. (1989), “Tourism destination Area development” (From Theory into Practice), in WITT S. \& MOUTINHO L. (1989).

VITTERS $\varnothing$ J., VORKINN M., VISTAD O. I. \& VAAGLAND J. (2000), “Tourist experiences and attractions", Annals of Tourism Research, 27, 2, pp. 432-450.

VOGT J. W. (1976), “Wandering, youth and travel behaviour”, Annals of Tourism Research, 4, 2, pp. 74-105 (quoted from PRYER, 1997).

WEAVER D. \& OPPERMANN M. (2000), Tourism management, John Wiley \& Sons, Australia, Brisbane.

WITT S. \& MOUTINHO L. (1989), Tourism Marketing and Management Handbook, Prentice Hall, New York, NY, USA. 


\section{ABSTRACTS}

Examining tourism is mostly taking place on a site or regional level. Travel, however, is a movement between such sites - from home to destination(s) and back to home again (Leiper, 1979). Trying to view tourism as a movement and a dynamic function means challenges. This paper is an attempt of modelling a "tourist route system" and to show what the use of different travelling pattern models means to "tourism route research" The aim is to show what dimensions will be lacking if studies only are focused on markets, sites or destinations.

L'analyse du tourisme se place avant tout au niveau d'un site ou d'une région, mais le voyage représente un déplacement entre ces lieux - du domicile jusqu'à destination et retour (Leiper, 1979). Tenter de voir le tourisme comme un mouvement et une fonction dynamique représente un défi. Dans cet article, nous essayons de modéliser un "système d'itinéraire touristique" et de démontrer ce que l'utilisation de différents modèles de schémas de voyage signifie pour la recherche en matière d'itinéraires touristiques. Notre objectif est de montrer quelles dimensions seront manquantes si les études ne se focalisent que sur les marchés, les sites ou les destinations.

\section{INDEX}

Keywords: tourism, en-route-models, modes of travel, segmentation

Mots-clés: tourisme, modèles de circuits touristiques, modes de déplacement, segmentation

\section{AUTHOR}

\section{THOR FLOGNFELDT JR.}

Lillehammer University College, Norway, Thor.Flognfeldt@hil.no 